\title{
SECONDARY OSTEOPOROSIS DUE TO SICKLE CELL ANEMIA: DO SEX STEROIDS PLAY A ROLE?
}

MIR SADAT-ALI, ABDULMOSHSEN AL-ELQ, OSAMA SULTAN, HAIFA AL-TURKI

\section{ABSTRACT}

BACKGROUND: The exact cause of osteoporosis in patients with sickle cell disease $(S C D)$ is not known, and various hypotheses have been put forward. AIM: To assess the effect of sex steroids on bone mass in SCD patients. Settings and Design: In King Fahd Hospital of the university, Alkhobar, Saudi Arabia, a cross-sectional study was carried out. MATERIALS AND METHODS: All patients know $n$ to suffer from SCD attending the hospital between August 2006 and August 2007 were subjects of the study. Blood was extracted for serum level of androgens, gonadotropins, thyroid stimulating hormone (TSH), calcium, phosphorus, and alkaline phosphatase. Measurement of bone mineral density (BMD) of hip and spine was done using dual-energy X-ray absorptiometry (DEXA). All tests were performed using SPSS (Statistical Package for Social Sciences), version 14.0, Chicago, Illinois, with $P$ value of $<0.05$ being statistically significant with confidence interval $(\mathrm{CI})$ of $95 \%$. RESULTS: O ne hundred three consecutive patients with an average age of 27.83 years were studied. Forty-five were males; and 58 , females. Low bone mass (osteoporotic/osteopenic) was found in $62.2 \%$ of the patients in the male group and $67.06 \%$ in the female group. In males, testosterone level was not significant between different groups, but total estradiol levels were significantly lower in the osteopenic and osteoporotic patients $(P<0.003$ and $<0.01$ respectively). In female patients, estradiol and testosterone levels were lower in osteoporotic patients in comparison to non-osteoporotic patients ( $P=0.05$ and 0.001$)$. CONCLUSIONS: O ur study indicates that sex steroids play a major role in the development of osteopenia and osteoporosis in patients with SCD

Key words: Estradiol, osteoporosis, sickle cell disease, testosterone

College of Medicine, King Faisal University, Dammam and King Fahd University Hospital, AlKhobar, Saudi Arabia, Mir Sadat-Ali (Dept. of Orthopaedic Surgery), AbdulMohsen Al-Elq and Osama Sultan (Dept. of Internal Medicine), Haifa A Al-Turki (Dept of Obstetrics and Gynecology)

\section{Correspondence:}

Prof. Mir Sadat-Ali

P. BOX 40071 King Fahd University Hospital,

Al-Khobar 31952, Saudi Arabia. E-mail: drsadat@hotmail.com

\section{INTRODUCTION}

The prevalence of osteoporosis in premenopausal Saudi Arabian women is reported to be $10 \%$; and in postmenopausal women, between $30 \%$ and $40 \%$, which is higher in comparison to that in other parts of the world ${ }^{[1-4]} \operatorname{In} 20 \%$ to $30 \%$ of postmenopausal women and in more than $50 \%$ of men, osteoporosis is due to secondary causes. ${ }^{[5]}$ Bones are sensitive to diseases, which may cause secondary osteoporosis such as hormonal and due to drugs like steroids and chemotherapeutic agents. ${ }^{[6]}$ Recently SCD has been added to the list of diseases which cause secondary osteoporosis. ${ }^{[7-10]}$

The importance of testosterone in men with osteoporosis has been challenged now, and reports indicate that in primary osteoporosis, estrogen is the important hormone in the prevention of osteoporosis in both sexes. ${ }^{[11-15]}$ Since the role of sex steroids in secondary osteoporosis in SCD has not been previously studied, the objective of this study was to identify the role of estrogen and testosterone in young men and women with SCD.

\section{MATERIALS AND METHODS}

All patients known to suffer from SCD attending the outpatient clinics and admitted to King Fahd Hospital of the university, Alkhobar, Saudi Arabia, between August 2006 and August 2007 were subjects of the study. After obtaining ethical approval from the research and scientific committee of College of Medicine, King Faisal University, Dammam, the study was started. Verbal consent was obtained. The patients had their weight and height measured to calculate the body mass index (BMI). History was taken and clinical examination was done and followed by appropriate investigations to rule out secondary osteoporosis. Patients who were diagnosed and treated for osteopenia and osteoporosis and those patients who were on steroids; had anorexia nervosa, hyperthyroidism, chronic obstructive pulmonary disease, liver and inflammatory bowel disease or had undergone organ transplantation were excluded from the study. All blood samples were collected before $10 \mathrm{AM}$ for tests which included complete blood picture, hemoglobin electrophoresis, blood urea nitrogen, creatinine level, calcium, phosphorous, alkaline phosphatase, parathormone level, thyroid stimulating hormone (TSH), luteinizing hormone (LH), follicle stimulating hormone (FSH), tota estradiol (E2), and total testosterone (Te); and the hormonal assay was done with Architec 2000 machine using the chemiluminescent microparticle immuno-assay (CMIA). The gonadotropin assays in females were done 21 days from the first day of the cycle. Bone mineral density (BMD) measurement of hip area and lumbar spine (lumbar 1 to lumbar 4 vertebra) using dual-energy $x$-ray absorptiometry (DEXA) scan, Hologic Inc., Waltham, MA, USA was performed. Patients with a $T$ score of $\leq 2.5$ SD or below were taken as osteoporotic and those between $\leq 1$ and -2.5 SD were taken as osteopenic for analysis. The reference value of $T$ and $Z$ score was entered in the DEXA machine with software for the Asian values. Secondary osteoporosis was ruled out on the basis of drug history and blood tests whic included complete blood picture, serum calcium phosphorus, alkaline phosphatase, thyroid stimulating hormone, serum estradiol, serum testosterone, and parathormone levels. ${ }^{[16]}$ The data was entered in the database and analyzed using a $t$ test to compare means between the non-osteoporotic, osteopenic, and osteoporotic patients. All tests were performed using SPSS (Statistical Package for Social Sciences), ${ }^{117}$ version 14.0, Chicago, Illinois, with $P$ value of $<0.05$ being statistically significant with confidence interval $(\mathrm{Cl})$ of $95 \%$. 


\section{RESULTS}

One hundred three patients with homozygous sickle cell anemia had an average age of $27.8 \pm 6.7$ years. Forty-five were males and 58 were females. Table 1 gives data of the male patients. In the male group, $62.2 \%$ of the patients had low bone mass (osteoporotic/ osteopenic). In patients who were nonosteoporotic, the BMI was significantly higher compared to that in osteoporotic patients $[19 \pm 4.1$ vs. $16.7 \pm 4.4 ; P=0.05(95 \% \mathrm{Cl}, 4.6-$ 6.5)]. Table 2 shows the results of sex steroids and bone mineral density in male patients. Ninety-five percent of the patients had blood

transfusion more than once, and $69(66.9 \%)$ patients had bone and joint complications.

There was no statistically significant difference in the levels of testosterone between the nonosteoporotic, osteopenic, and osteoporotic patients $(P=0.5)$. Osteoporotic patients had lower estradiol level $(24.5 \mathrm{pg} / \mathrm{mL})$ in comparison to non-osteoporotic patients $[30.1 \mathrm{pg} / \mathrm{mL} ; P=$ 0.01 (95\% Cl, 0.41-11.6)]. In the female group, the BMI was significantly lower in osteopenic and osteoporotic patients $[P=0.01$ and 0.05 $(95 \% \mathrm{Cl}, 1.4-7.8$ and 4.6-6.5) respectively] [Table 3]. Osteopenia was observed in $31.3 \%$ and osteoporosis in $36.3 \%$ of the patients, and

Table 1: Demographic data of male patients

\begin{tabular}{|c|c|c|c|c|c|}
\hline Parameter & $\begin{array}{c}\text { Normal (Group 1) } \\
\text { Mean } \pm S D\end{array}$ & $\begin{array}{l}\text { Osteopenia (Group 2) } \\
\text { Mean } \pm S D\end{array}$ & $\begin{array}{c}\text { Osteoporosis (Group 3) } \\
\text { Mean } \pm S D\end{array}$ & $\begin{array}{l}P \text { value Group } 1 \\
\text { and } 2\end{array}$ & $\begin{array}{l}P \text { value Group } 1 \\
\text { and } 3\end{array}$ \\
\hline Number & $17(37.7 \%)$ & $13(28.8 \%)$ & $15(33.4 \%)$ & & \\
\hline Age (Years) & $28.5(20-42)$ & $26.6(22-36)$ & $27.7(18-41)$ & NS & NS \\
\hline $\begin{array}{l}\mathrm{BMI} \mathrm{kg} / \mathrm{M}^{2} \\
\text { Hemoglobin }\end{array}$ & $19 \pm 4.1$ & $17.1 \pm 4.0$ & $16.7 \pm 4.4$ & 0.08 & 0.05 \\
\hline $\begin{array}{l}\text { 'S' (\%) } \\
\text { Hemoglobin }\end{array}$ & $87.3 \pm 4.4$ & $84.9 \pm 4.3$ & $86.3 \pm 4$ & NS & NS \\
\hline $\begin{array}{l}\text { Concentration } \\
(\mathrm{g} / \mathrm{ll}\end{array}$ & $9.5 \pm 0.9$ & $9.4 \pm 0.9$ & $9.7 \pm 1.2$ & NS & NS \\
\hline $\begin{array}{l}\text { BUN } \\
\text { BUN }\end{array}$ & $10.3 \pm 1.5$ & $8 \pm 4.7$ & $7.2 \pm 4.5$ & NS & NS \\
\hline Creatinine & $0.6 \pm 0.1$ & $0.5 \pm 0.2$ & $0.4 \pm 0.1$ & NS & NS \\
\hline Calcium & $8.8 \pm 0.3$ & $9 \pm 0.2$ & $9.1 \pm 0.2$ & NS & NS \\
\hline $\begin{array}{l}\text { Phosphorus } \\
\text { Alkaline }\end{array}$ & $3.5 \pm 0.4$ & $3.8 \pm 0.4$ & $4.1 \pm 0.5$ & NS & NS \\
\hline Phosphatase & $143.8 \pm 83.6$ & $131.6 \pm 48$ & $147.7 \pm 26.7$ & NS & NS \\
\hline
\end{tabular}

Table 2: Sex steroids and bone mineral density of male patients

\begin{tabular}{|c|c|c|c|c|c|}
\hline $\begin{array}{l}\text { Parameter and } \\
\text { normal values }\end{array}$ & $\begin{array}{l}\text { Normal (Group 1) } \\
\text { Mean } \pm S D\end{array}$ & $\begin{array}{l}\text { Osteopenia (Group 2) } \\
\text { Mean } \pm S D\end{array}$ & $\begin{array}{c}\text { Osteoporosis (Group 3) } \\
\text { Mean } \pm S D\end{array}$ & $\begin{array}{l}P \text { value Group } 1 \\
\text { and } 2\end{array}$ & $\begin{array}{l}P \text { value Group } 1 \\
\text { and } 3\end{array}$ \\
\hline Number of patients & $17(37.7 \%)$ & $13(28.8 \%)$ & $15(33.4 \%)$ & & \\
\hline $\begin{array}{l}>50 \mathrm{ng} / \mathrm{dl} \\
\text { Total Estradiol }\end{array}$ & $420.3 \pm 220.9$ & $389.7 \pm 205.9$ & $390.1 \pm 91.1$ & 0.5 & 0.5 \\
\hline $11-44 \mathrm{pg} / \mathrm{ml}$ & $30.1 \pm 11.7$ & $24.5 \pm 4.5$ & $22.5 \pm 13$ & 0.01 & 0.01 \\
\hline LH $1.26-10(\mathrm{MIU} / \mathrm{ml})$ & $2.6 \pm 1.2$ & $6.2 \pm 2.9$ & $5.6 \pm 1.2$ & 0.01 & 0.01 \\
\hline FSH $1.37-13.58(\mathrm{MIU} / \mathrm{ml})$ & l) $1.5 \pm 0.73$ & $3.8 \pm 2.6$ & $4.2 \pm 0.8$ & 0.01 & 0.01 \\
\hline TSH & $1.5 \pm 0.7$ & $1.8 \pm 1$ & $1.9 \pm 0.8$ & 0.1 & 0.1 \\
\hline Total Hip BMD g/ $/ \mathrm{cm}^{2}$ & $1.084 \pm 0.13$ & $0.868 \pm 0.10$ & $0.592 \pm 0.05$ & 0.01 & 0.01 \\
\hline T Score & $-0.03 \pm 0.67$ & $\begin{array}{l}-1.525 \pm 0.20 \\
-1.325+0.44\end{array}$ & $\begin{array}{l}-2.65 \pm 0.05 \\
-22+0.39\end{array}$ & & \\
\hline L1-L4 Spine BMD g/ $/ \mathrm{cm}^{2}$ & $1.115 \pm 0.14$ & $0.868 \pm 0.13$ & $\begin{array}{l}-2.2 \pm 0.39 \\
0.651 \pm 0.09\end{array}$ & 0.01 & 0.01 \\
\hline T Score & $0.19 \pm 1.48$ & $-2.08 \pm 0.67$ & $-3.9 \pm 0.09$ & & \\
\hline Z Score & $-1-1.0 \pm 0.61$ & $-2.08 \pm 0.67$ & $-3.2 \pm 0.62$ & & \\
\hline
\end{tabular}

Table 3: Demographic data of female patients

\begin{tabular}{|c|c|c|c|c|c|}
\hline Parameter & $\begin{array}{c}\text { Normal (Group 1) } \\
\text { Mean } \pm S D\end{array}$ & $\begin{array}{c}\text { Osteopenia (Group 2) } \\
\text { Mean } \pm \text { SD }\end{array}$ & $\begin{array}{c}\text { Osteoporosis (Group 3) } \\
\text { Mean } \pm S D\end{array}$ & $\begin{array}{l}P \text { value Group } 1 \\
\text { and } 2\end{array}$ & $\begin{array}{l}P \text { value Group } 1 \\
\text { and } 3\end{array}$ \\
\hline Number & $19(32.7 \%)$ & $18(31.03 \%)$ & $21(36.3 \%)$ & & \\
\hline Age (Years) & $28.9(25-40)$ & $26(24-29)$ & $29.1(22-41)$ & NS & NS \\
\hline $\mathrm{BMI} \mathrm{kg} / \mathrm{M}^{2}$ & $20.1 \pm 4.9$ & $15.5 \pm 5.1$ & $16.6 \pm 4.9$ & 0.01 & 0.05 \\
\hline $\begin{array}{l}\text { Hemoglobin 'S' (\%) } \\
\text { Hemoglobin }\end{array}$ & $89.5 \pm 4.2$ & $85.2 \pm 3.9$ & $86.7 \pm 3.7$ & NS & NS \\
\hline Concentration (g/l) & $9.5 \pm 1$ & $9.7 \pm$ & $9.4 \pm$ & NS & NS \\
\hline BUN & $6.2 \pm 2.45$ & $7.1 \pm 1.72$ & $7.1 \pm 2.4$ & NS & NS \\
\hline Creatinine & $0.54 \pm 0.18$ & $0.51 \pm 0.13$ & $0.41 \pm 0.09$ & NS & NS \\
\hline Calcium & $9 \pm 0.26$ & $8.8 \pm 0.37$ & $8.2 \pm 1.1$ & 0.01 & 0.01 \\
\hline Phosphorus & $3.6 \pm 0.37$ & $3.7 \pm 0.67$ & $3 \pm 0.83$ & NS & NS \\
\hline Alkaline Phosphatase & $93.7 \pm 32.4$ & $110.1 \pm 47.9$ & $125 \pm 58$ & 0.3 & 0.1 \\
\hline
\end{tabular}

the rest had normal bone mass. Table 4 shows that total testosterone levels were significantly lower in osteopenic and osteoporotic females $[P=0.05$ and $=0.001(95 \% \mathrm{Cl}, 2.3-198.5$ and 84.4-257.6) respectively]; whereas there was no difference between the estradiol levels of normal and osteopenic patients. The total estradiol levels in the osteoporotic patients were much lower when compared with the nonosteoporotic patients [43.5 vs. $61 \mathrm{pg} / \mathrm{mL} ; P=$ $0.05(95 \% \mathrm{Cl}, 4-38.9)]$.

\section{DISCUSSION}

Secondary osteoporosis is common, and young people suffer from steroid-induced

osteoporosis; ${ }^{[18]}$ SCD is emerging as the most common cause of secondary osteoporosis in the younger population. Studies have reported the incidence of osteoporosis to be $69 \%$ to $79 \%,{ }^{[7,9,19]}$ even though $5 \%$ of the world's population carries sickle cell gene. ${ }^{[20]}$ In Saudi Arabia, the gene is prevalent in $5.7 \%$ of the population. ${ }^{[21]}$ It appears there is complacency among physicians to diagnose and properly manage patients with secondary osteoporosis.

The exact cause or causes of osteoporosis in SCD are yet to be established. It was suggested that hyperplasia of the marrow may cause trabecular destruction. Faber et al. ${ }^{[22]}$ showed that chronic anemia causes

Table 4: Sex steroids and bone mineral density of female patients

\begin{tabular}{|c|c|c|c|c|c|}
\hline Parameter & $\begin{array}{c}\text { Normal (Group 1) } \\
\text { Mean } \pm S D\end{array}$ & $\begin{array}{c}\text { Osteopenia (Group 2) } \\
\text { Mean } \pm S D\end{array}$ & $\begin{array}{c}\text { Osteoporosis (Group 3) } \\
\text { Mean } \pm S D\end{array}$ & $\begin{array}{l}P \text { value Group } 1 \\
\text { and } 2\end{array}$ & $\begin{array}{l}P \text { value Group } 1 \\
\text { and } 3\end{array}$ \\
\hline $\begin{array}{l}\text { Number of patients } \\
\text { Total testosterone }\end{array}$ & $19(32.7 \%)$ & $18(31.03 \%)$ & 21 (36.3\%) & & \\
\hline $\begin{array}{c}>50 \mathrm{ng} / \mathrm{dl} \\
\text { Total estradiol }\end{array}$ & $190.4 \pm 192$ & $90 \pm 100.9$ & $19.4 \pm 13.9$ & 0.05 & 0.001 \\
\hline $\begin{array}{l}11-44 \mathrm{pg} / \mathrm{ml} \\
\text { LH } 1.26-10.05\end{array}$ & $61 \pm 40.25$ & $51.1 \pm 33.5$ & $43.5 \pm 26.9$ & 0.4 & 0.05 \\
\hline $\begin{array}{l}(\mathrm{MIU} / \mathrm{ml}) \\
\text { FSH } 1.37-13.58\end{array}$ & $9.3 \pm 19.19$ & $3.28 \pm 1.08$ & $10.99 \pm 18$ & 0.05 & 0.1 \\
\hline & $\begin{array}{c}4.90 \pm 2.53 \\
1.9 \pm 0.66\end{array}$ & $\begin{array}{c}4.16 \pm 1.23 \\
1.3 \pm 0.6\end{array}$ & $\begin{array}{c}13.04 \pm 24.1 \\
1.09 \pm 0.3\end{array}$ & $\begin{array}{l}0.1 \\
0.1\end{array}$ & $\begin{array}{c}0.001 \\
0.1\end{array}$ \\
\hline $\begin{array}{l}\text { Total Hip BMD } \\
\text { g/cm² } \\
\text { T Score }\end{array}$ & $\begin{array}{l}0.995 \pm 0.15 \\
0.062 \pm 0.71\end{array}$ & $\begin{array}{l}0.772 \pm 0.09 \\
-1.5 \pm 0.37\end{array}$ & $\begin{array}{c}0.536 \pm 0.08 \\
-3.1 \pm 0.56\end{array}$ & 0.03 & 0.001 \\
\hline Z Score & $0.231 \pm 0.77$ & $-1.6 \pm 0.31$ & $-2.65 \pm 0.58$ & & \\
\hline $\begin{array}{l}\text { BMD L1-L4 Spine } \\
\text { T Score }\end{array}$ & $\begin{array}{l}0.995 \pm 0.15 \\
-0.47 \pm 1.31\end{array}$ & $\begin{array}{l}0.770 \pm 0.06 \\
-2.50 \pm 0.52\end{array}$ & $\begin{array}{l}0.617 \pm 0.08 \\
-4.2 \pm 1.06\end{array}$ & 0.03 & 0.001 \\
\hline Z Score & $-0.28 \pm 1.34$ & $-2.41 \pm 0.55$ & $-3.76 \pm 1.15$ & & \\
\hline
\end{tabular}


increase in trabecular spacing, which leads to trabecular destruction, which in turn causes osteopenia or osteoporosis. It was reported that in patients with $\mathrm{Hb} \beta$-thalassemia, osteopenia and osteoporosis occur due to marrow expansion. ${ }^{[23]}$ Gurevitch and Slavin ${ }^{[24]}$ put forward a hypothesis of hematological cause of osteoporosis. In our patients, we did not encounter any significant differences regarding the hematological parameters between normal, osteopenic, and osteoporotic patients.

Seeman ${ }^{[25]}$ found that in $20 \%$ to $30 \%$ of elderly men, osteoporosis occurred due to lack of testosterone. In our study, only one male patient had testosterone level below the normal range, and none of the other patients had normal estradiol levels. Our male osteoporotic patients had the lowest estradiol levels. Recently Karim and his associates ${ }^{[26]}$ raised another issue, that of FSH being one of the gonadotropins which could be implicated in the bone loss independent of estrogen. Our results concur with those of the said study.

The limitations of this study are few. All efforts were made to rule out other causes of secondary osteoporosis on the basis of clinical and laboratory tests, but still we could have missed some patients. Secondly, we did not perform test for determining vitamin $D$ level in these patients, which may play a minor role in osteopenia and osteoporosis. In conclusion, this study suggests that sex steroids play an important role in causing low bone mass in young patients with SCD. Hence measurement of estrogen levels is essential in the evaluation of male osteoporosis; and in females, both testosterone and estradiol levels should be determined in the evaluation of osteoporosis.

\section{REFERENCES}

1. Ardawi MS, Maimany AA, Bahksh TM, Nasrat HA Milaat WA, Al-Raddadi RM. Bone mineral density of the spine and the femur in healthy Saudis. Osteoporosis Int 2005;16:43-55.

2. Sadat-Ali M, Al-Habdan I, Al-Mulhim FA, El-Hassan AY. Bone mineral density among postmenopausal Saudi women. Saudi Med J 2004;25:1623-5.

3. Sadat-Ali M, Al-Habdan I, Marwah S. Bone mineral density measurements of distal radius in Saudi Arabian females. Annals Saudi Med 1996;16:414-6.

4. El-Desouki M. Bone mineral density of the spine and femur in the normal Saudi population. Saudi M J 1995;16:30-5.

5. Fitzpatrick LA. Secondary causes of osteoporosis. Mayo Clin Proc 2002;77:1005-6.

6. Templeton K. Secondary osteoporosis. J Am Acad Orthop Surg 2005;13:475-86.

7. Sadat-Ali M, AlElq AH. Sickle cell anemia: Is it a cause for secondary osteoporosis? West Afr J Med 2007;26:134-7.

8. Sarrai M, Duroseau H, D'Augustine J, Moktan $\mathrm{S}$, Bellevue R. Bone mass density in adults with sickle cell disease. Br J Haematol 2007;136: 666-72.

9. Miller RG, Segal JB, Ashar BH, Leung S, Ahmed S, Siddique $S$, et al. High prevalence and correlates of low bone mineral density in young adults with sickle cell disease. Am J Hematol 2006;81: 236-41.

10. Brinker MR, Thomas KA, Myers SJ, Texada T, Humbert JR, Cook SD, et al. Bone mineral density of the lumbar spine and proximal femur decreased in children with sickle cell anemia. Am J Orthop 1998;27:43-9

11. Sadat-Ali M, Al-Elq AM. Effect of androgens on bone mineral density in Saudi Arabian males above the age of 50 years. Saudi Med J 2007:28:1247-50.

12. Khosla S, Melton LJ 3rd, Riggs BL. Estrogens and bone health in men. Calcific Tissue Int
2001;69:189-92.

13. Szulc $P$, Munoz F, Claustrat B, Garnero $P$, Marchand F, Duboeuf $F$, et al. Bioavailable Estardiol may be important determinant of osteoporosis in men: the MINOS study. J Clin Endocrinol Metab 2001;86:192-9.

14. Amin S, Zhang Y, Sawin CT, Evans SR, Hannan MT, Kiel DP et al. Association of Hypogonadism and estradiol levels with bone mineral density in elderly men from the Framingham study. Ann Intern Med 2000;133:951-63.

15. Khosla S, Melton LJ 3rd, Aitkin EJ, O'Fallon WM, Klee GG, Riggs BL. Relationship of serum sex steroid levels and bone turnover markers with bone mineral density in men and women. A key role for bioavailable estrogen. J Clin Endocrinol Metab 1998:83:2266-74.

16. CooperA, BrewS, de Lusignan S. The effectiveness of blood tests in detecting secondary osteoporosis or mimicking conditions in postmenopausal women. Br J Gen Pract 2002;52:311-3.

17. SPSS statistical software package, version 14.0. Chicago, Illinois: SPSS Inc; 2007

18. Hansen LB, Vondracek SF. Prevention and treatment of nonpostmenopausal Osteoporosis. Am J Health Syst Pharm 2004;61:2637-54.

19. Sarrai M, Duroseau H, D'Augustine J, Moktan $\mathrm{S}$, Bellevue R. Bone mass density in adults with sickle cell disease. Br J Haematol 2007;136:
666-72.

20. Prevalene of sickle cell anemia. WHO 2006;A59/9.

21. el-Hazmi MA, Warsy AS, al-Swailem AR, al-Swailem AM, Bahakim HM. Sickle cell gene in the population of Saudi Arabia. Hemoglobin 1996;20:187-98.

22. Faber TD, Yoon DC, White SC. Fourier analysis reveals increased trabecular spacing in sickle cell anemia. J Dent Res 2002;81:214-8.

23. Voskaridou E, Stoupa E, Antoniadou L, Premetis E, Konstantopoulos K, Papassotirio $\mathrm{I}$, et al. Osteoporosis and osteosclerosis in the sickle cell/ $\beta$-thalassemia: The role of th RankL/osteoprogeterin axis. Hematologica 2006;91:813-6.

24. Gurevitch O, Slavin S. The hematological etiolog of osteoporosis. Med Hypotheses 2006;67 729-35.

25. Seeman E. Pathogenesis of bone fragility in women and men. Lancet 2002;359:1841-50.

26. Karim N, MacDonald D, Dolan AL, Fogelman I, Wierzbicki AS, Hampson G. The relationship between gonadotropins, gonadal hormones and bone mass in men. Clin Endocrinol 2007; Aug 29; [Epub ahead of print].

Source of Support: Nil
Conflict of Interest: None declared. 